Reprod. Nutr. Dévelop., 1984, 24 (5A), 529-541.

\title{
Effect of conceptus removal and intrauterine administration of conceptus tissue on luteal function in the cow
}

\author{
P. HUMBLOT, M. A. DALLA PORTA (1)
}

Union nationale des Coopératives d'Elevage

et d'Insémination artificielle (U.N.C.E.I.A.), Services techniques,

13, rue Jouët, B.P. 65, 94703 Maisons-Alfort, France.

Summary. Two experiments were conducted to determine the day on which the bovine embryo first affects luteal function.

Experiment I was to determine the sole effect of flushing the uterine lumen and involved 12 non-inseminated heifers flushed 9,14 and 16 days after estrus ( 4 animals per group). The same procedure was used to remove conceptuses from 15 pregnant heifers on days $9(n=4), 14(n=5)$ and $16(n=7)$ after the onset of estrus. Progesterone concentrations were measured daily throughout the cycle corresponding to conceptus removal (or flushing alone) and throughout the preceding cycle. In non-inseminated animals and when the conceptuses were removed on days 9 or 14, neither the progesterone pattern nor the inter-estrous interval was altered. By contrast, when the embryo was removed on day 16 , the time of luteolysis was delayed by 4 to 7 days and the heifers were observed to be in estrus 26 to 29 days after Al.

In experiment 2, 21 virgin heifers were distributed over four treatment groups. Animals in groups 2 to 4 received the following treatments twice a day between day 15 and day 19 of the estrous cycle in the horn ipsilateral to the corpus luteum : group $2(\mathrm{n}=3$ ), $0,25 \mathrm{ml}$ saline ; group 3 ( $n=3$ ), two 12-day-old conceptuses; group 4 ( $n=5)$, one 16-day-old conceptus. Progesterone concentrations were determined from day 13 of the cycle to 4 days after the following estrus. No antiluteolytic effect was found with intrauterine administration of either saline alone or day- 12 embryos. In contrast, administration of day16 conceptuses through the cervix (group 4) lengthened the estrous cycle by 6 to 7 days.

The results of these experiments suggest that the antiluteolytic and/or luteotropic factor(s) originating from the conceptus is fully potent by day 16 . Embryonic mortality occuring on day 16 or later may induce an extension of corpus luteum lifespan.

\section{Introduction.}

Early pregnancy maintenance in the cow, as in other mammals, requires extended corpus luteum lifespan which is supported by luteotropic and/or antiluteolytic signals produced by the conceptus. In the ewe and the cow, evidence of luteotropic factors has been found both in both in vitro and in vivo

(1) Adresse actuelle : Universidade Federal de Santa Maria, Departemento Zootecnica, 97100 Santa Maria, Brasil. 
experiments (Beal et al., 1981 ; Bulman and Lamming, 1978 ; Lukazewska and Hansel, 1980). Nevertheless, in these species, the mechanism by which the conceptus prevents luteolysis is not yet completely elucidated. In the ewe, PGE2 or other prostanoids (Henderson et al., 1977 : Lewis et al., 1978 ; Pratt et al., 1979 ; Marcus, 1981) and a protein of trophoblastic origin (Martal et al., 1979) may be involved in corpus luteum maintenance. In bovines, Northey and French (1980) reported that the embryonic signal(s) may be given between days 15 and 17 , but the chronological aspects of the interaction between the conceptus and ovary, as well as its consequences on corpus luteum function and estrous cycle length, were not completely determined.

The aims of the present study were to investigate the effects of (1) conceptus removal from the uterus at different stages following conception and of (2) transcervical intrauterine administration of frozen conceptuses of precise ages on corpus luteum function and $(3)$ to determine the possible chronological relationship between conceptus death and the alteration of estrous cycle length.

\section{Materials and methods.}

\section{Animals and preliminary treatments.}

Sexually mature heifers (18 to 24 months old) of the French Friesian (FFPN) or FFPN $\times$ Limousine breeds, kept in a free stall area and fed essentially with maize silage, were used in this study. Before the beginning of the experiments, estrus was synchronized using a combination of a progesterone intravaginal device (Prid, Ceva France) left in place for 12 days and an intramuscular injection of $0,5 \mathrm{mg}$ of prostaglandin $\mathrm{F}_{2 \alpha}$ analog (Cloprostenol : Uniandine, ICl France) administered two days before PRID removal. After the synchronization of estrus and throughout the subsequent estrous cycles heifers were routinely checked for estrus twice a day (from 7 to 9 a.m. and 6 to 8 p.m.). Only heifers exhibiting standing estrus were used in these experiments.

\section{Experiment 1: Effect of the flushing procedure and of conceptus removal on luteal function.}

Fifty-two heifers were distributed into two treatment groups. The animals in group 1 were used to study the effect of flushing the uterus on the length of the estrous cycle. In this group 12 heifers which had not been previously inseminated were flushed 9, 14 and 16 days ( 4 animals per day) after the onset of estrus (fig. 1) by the transcervical procedure initially described by Ozil et al. (1979). The catheter was introduced through the cervix into the uterine horn ipsilateral to the corpus luteum. A total volume of $300 \mathrm{ml}$ of phosphate-buffered saline (PBS) was injected in small fractions $(30$ to $50 \mathrm{ml}$ ) and collected.

In group 2 forty heifers were inseminated and the uterus was subsequently flushed by the same procedure on days $9(n=18), 14(n=6)$ and $16(n=16)$ after Al. The presence of a conceptus was determined after collection of the flushing and, in these females, 4 day $-9,5$ day -14 and 7 day -16 conceptuses were found. All heifers were subjected to $\mathrm{Al}$ and uterine flushings 
a

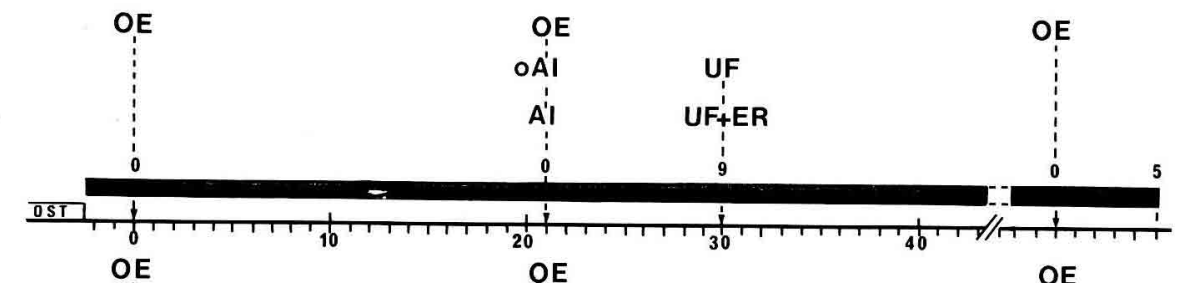

b

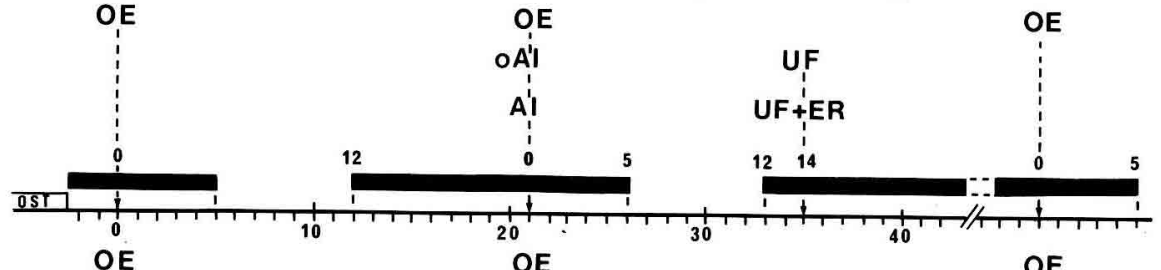

c

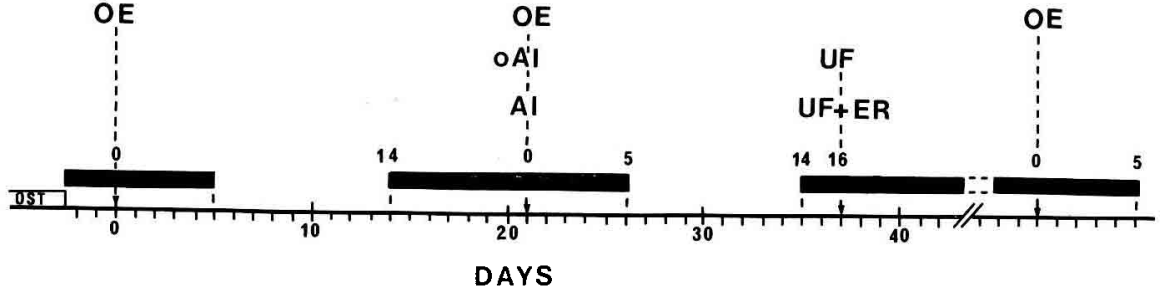

FIG. 1. - Effect of the flushing procedure and conceptus removal on days 9 (a), 14 (b) and 16 (c). Experimental desian when second estrus is observed 21 days after the first. ST: Estrus synchronization treatment; OE : Estrus; Al: Artificial insemination; UF : Uterine flushing; ER : Embryo removal ; Sampling periods.

after the second estrus following synchronization of estrus. All animals were inseminated twice with the semen of one bull. The first Al was performed 12 hours after the beginning of estrus and the second Al 12 hours later.

For heifers flushed on day 9 (inseminated or not), plasma samples were obtained daily for progesterone determination throughout two consecutive cycles from the end of the estrus synchronization regimen to day 5 after the estrus following the flushing procedure (fig. 1). Heifers flushed on days 14 and 16 (inseminated or not) were bled during two consecutive cycles, $i$. e. between days 0 and 5 and between days 12 and 14, respectively, to 5 days after the following estrus (fig. 1).

\section{Experiment 2 : Intrauterine administration of conceptus tissue.}

The conceptuses used in this experiment (thirty 12-day-old conceptuses and approximately, fifty 16-day-old conceptuses) were obtained from 30 superovulated cows either by the transcervical procedure described previously or after collection of the genital tracts at the slaughterhouse. The embryos were sorted according to morphological criteria. All the conceptuses or pieces of conceptus wich were degenerated were discarded. After collection, the conceptuses were immediately sucked into French straws $(0,25 \mathrm{ml})$ and stored in liquid nitrogen $\left(-196^{\circ} \mathrm{C}\right)$ until used. 
The treated heifers were divided into 4 groups. Group 1 ( $n=10$ ) received no intrauterine treatment; in groups 2 to 4 the heifers were injected in the horn ipsilateral to the corpus luteum twice a day $(9 \mathrm{a} . \mathrm{m}$. and $6 \mathrm{p} . \mathrm{m}$.) between days 15 and 19 with either $0,25 \mathrm{ml}$ of saline solution (group $2, \mathrm{n}=3$ ), two 12-day-old conceptuses in $0,25 \mathrm{ml}$ of saline solution (group $3, \mathrm{n}=3$ ), or $0,25 \mathrm{ml}$ of 16-dayold conceptus tissue (group $4, n=5$ ), respectively.

The saline solution and day-12 conceptuses were introduced with a $4 \mathrm{~mm} \varnothing$ transfer catheter (Rusch RFA) with a subterminal opening. Day-16 conceptuses were introduced with a $4 \mathrm{~mm} \varnothing$ inseminating catheter (IMV France) with an axial opening.

The treatment solutions were administered intrauterinely after epidural anesthesia with $4 \mathrm{ml}$ of a solution of propoxycaine (Silvocaine N.D.).

Blood samples were obtained daily from each heifer for progesterone determination from day 13 after the onset of the first estrus following the synchronization of estrus until day 5 after the onset of the second estrus.

Blood sampling and progesterone radioimmunoassay. - Peripheral blood $(15 \mathrm{ml})$ was collected from the jugular vein into heparinized vacutainers (Beckton Dikinson, France). Plasma was immediately separated by centrifugation and stored at $-20^{\circ} \mathrm{C}$ until progesterone assay.

An assay procedure previously described and validated by Thibier and Saumande (1975) was use to analyse single aliquots of plasma. Antiserum 111/6 (Specific antisera LTD 1981, UK) raised in goat against progesterone $-11 \alpha$ succinyl BSA was used at a final dilution of $1 / 10000$. This antiserum displayed more than $12 \%$ cross-reactivity with $17 \alpha$-hydroxyprogesterone. The two steroids were separated by sephadex LH 20 microcolumn chromatography. The accuracy and efficiency of this separation procedure were satisfactory as reported previously (Thibier et al., 1973). The sensitivity of this assay was estimated to be $0.05 \mathrm{ng} / \mathrm{ml}$. The intraassay and interassay coefficients of variation were 15,4 and $17,3 \%$, respectively (10 determinations).

Analysis of data. - In both experiments, the length of the estrous cycle was estimated by the intervals between successive estruses (day 0 was designated as the first day of standing estrus). Estrus was further confirmed by complete luteolysis (i. e. progesterone concentrations lower than $1 \mathrm{ng} / \mathrm{ml}$ ). In experiment I these data were collected over two consecutive cycles. Each heifer was its own control thus minimizing the effect of individual variability. It has been shown that the length of the estrous cycle and the area under the progesterone curve in successive cycles are reproducible (Yenikoye et al., 1981, Humblot et al., 1981).

\section{Results}

Effect of the uterine flushing procedure. - In noninseminated animals (group 1), when uterine flushing was performed on either day 9, 14 or 16 of the

FIG. 2. - Effect of uterine flushing on days $9(\mathrm{a}, \mathrm{n}=4), 14(\mathrm{~b}, \mathrm{n}=4)$ and $16(\mathrm{c}, \mathrm{n}=4)$ of the estrous cycle on plasma progesterone concentrations ( $\mathrm{X} \pm \mathrm{S}$.E.). $\downarrow$ Day of estrus, $\checkmark$ Day of uterine flushing; 0 -.---ocontrol cycle, Cycle during which uterine flushing was performed. 

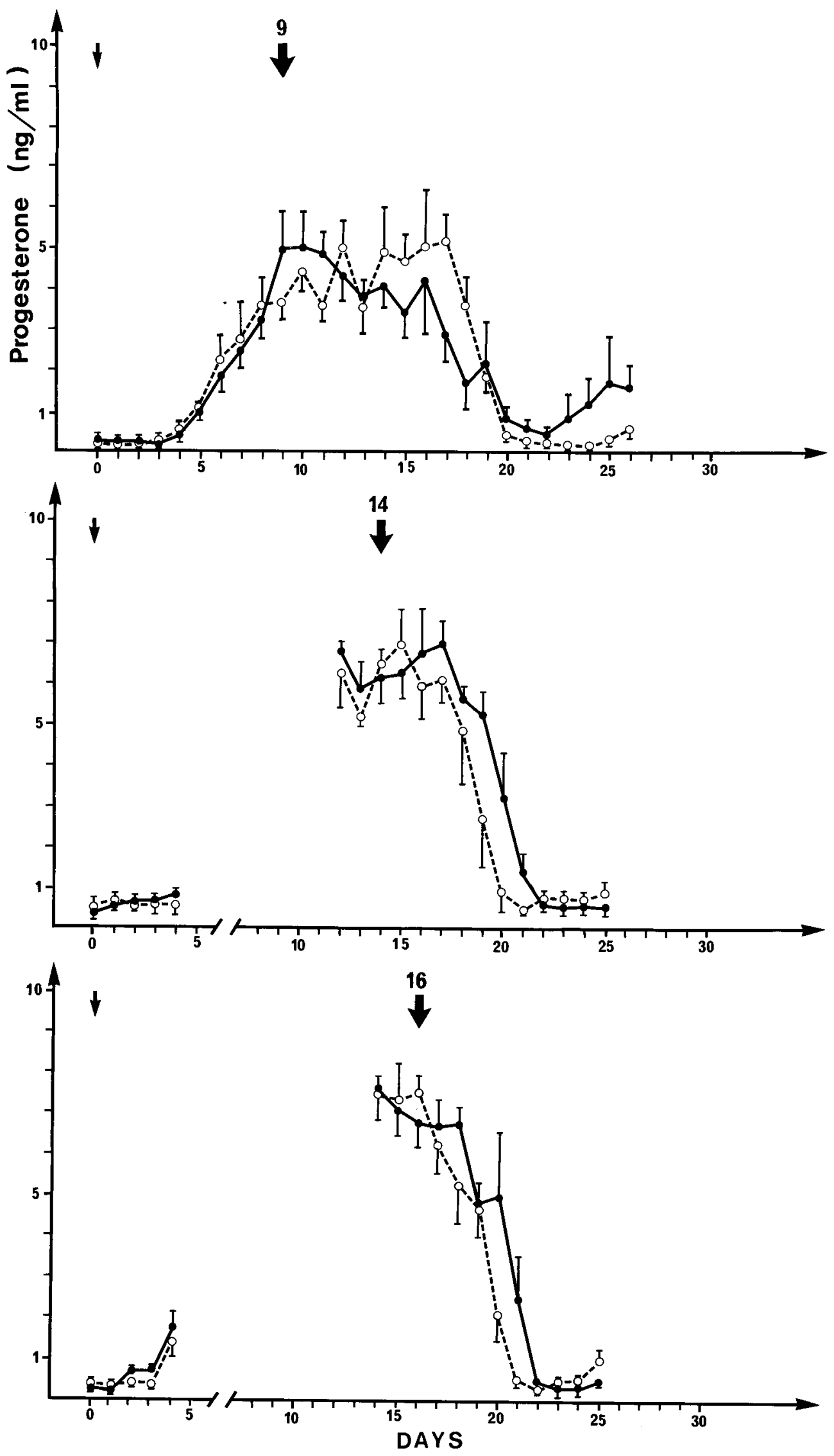
Effect of uterine flushing (U.F.) and conceptus removal (E. R.) 9, 14 and 16 days after estrus on interestrous intervals ( $\mathrm{N}=$ number of heifers).

\begin{tabular}{rccccc}
\hline Day & Treatment & $N$ & \multicolumn{3}{c}{ Estrous cycle length (days) } \\
\cline { 4 - 7 } & & & $\begin{array}{c}\text { Control } \\
\text { cycle } \\
\text { (mean } \pm \text { S. D.) }\end{array}$ & $\begin{array}{c}\text { U.F. or E.R. } \\
\text { cycle }\end{array}$ & S. \\
(mean \pm S. D.) & \\
\hline 9 & U.F. & 4 & $21.7 \pm 0.5$ & $21.0 \pm 2.0$ & N.S. \\
14 & U.F. & 4 & $20.3 \pm 0.6$ & $21.6 \pm 0.6$ & N.S. \\
16 & U.F. & 4 & $21.7 \pm 0.5$ & $22.2 \pm 0.5$ & N.S. \\
9 & E.R. & 4 & $22.2 \pm 1.5$ & $21.2 \pm 0.9$ & N.S. \\
14 & E.R. & 5 & $21.8 \pm 0.8$ & $21.0 \pm 0.7$ & N.S. \\
16 & E.R. & (*) $6^{*}$ & $21.2 \pm 0.4$ & $27.2 \pm 1.5$ & p $<0.001$ \\
\hline
\end{tabular}

${ }^{*}$ ) A conceptus was removed from one additional heifer, but complete luteolysis and estrus were not observed during the whole sampling period ( 35 days).

estrous cycle, the progesterone patterns and concentrations as well as interestrous * intervals (fig. 2 ; table 1) were very similar to those observed throughout the control estrous cycle. Consequently, no effect of the flushing procedure alone was found on luteal function at these three stages of the estrous cycle.

Effect of conceptus removal. - When the conceptuses were removed from the uterus either 9 or 14 days after conception, estrous cycle length was not significantly different from that of the control cycle (table 1), indicating no extension of corpus luteum lifespan (fig. 3 a and b).

By contrast, when embryos were removed 16 days after conception, luteolysis and the following estrus occurred 7 days later than expected (fig. $3 \mathrm{c}$; table 1), Six heifers were then observed to be in heat 26, 26, 26, 27, 29 and 29 days after Al. The mean progesterone concentrations observed between days 20 and 23 after $\mathrm{Al}$ were higher $(p<0.001)$ than those observed during the same period of the control cycle (fig. $3 \mathrm{c}$ ).

As shown by the individual progesterone profiles (fig. 4) of these six heifers, complete luteolysis occurred from 5 to 9 days later than in the control cycle. After conceptus removal, progesterone concentrations remained elevated and subsequently sharply declined to levels lower than $1 \mathrm{ng} / \mathrm{ml}$ within 24 hours. One additional heifer, from which a day-16 conceptus was removed, was not observed in estrus and failed to undergo complete luteolysis during the whole sampling period (fig. 4).

The length of day-16 conceptuses recovered ranged from 5 to $11 \mathrm{~cm}$ (mean $=7.8 \pm 1.9 \mathrm{~cm})$. No evidence of a relationship between the size of the conceptus and the delay of luteolysis was detected $(r=0,08)$.

FIG. 3. - Effect of conceptus removal on days 9 ( $\mathrm{a}, \mathrm{n}=4), 14$ (b, $\mathrm{n}=5)$ and 16 $(c, n=6$ ) after onset of estrus on plasma progesterone concentrations $(X \pm S . E$.). $\downarrow$ Day of estrus, $\forall$ Day of conceptus removal, $0--O$ Control cycle, $\longrightarrow$ Cycle during which the conceptus was removed. $\left(^{*}\right)$ Significant difference $(p<0.001$ ) detected by paired t-test. 

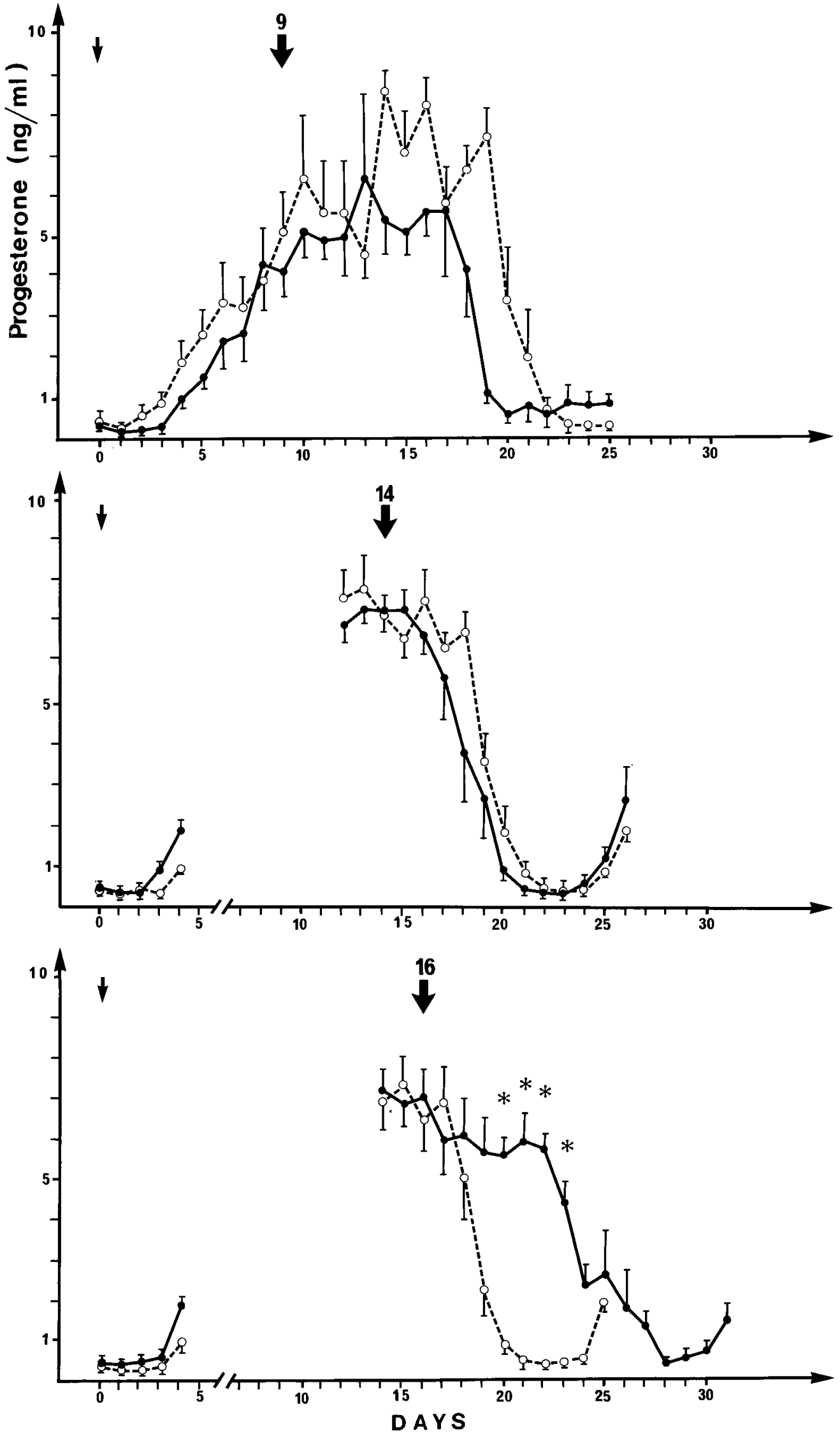


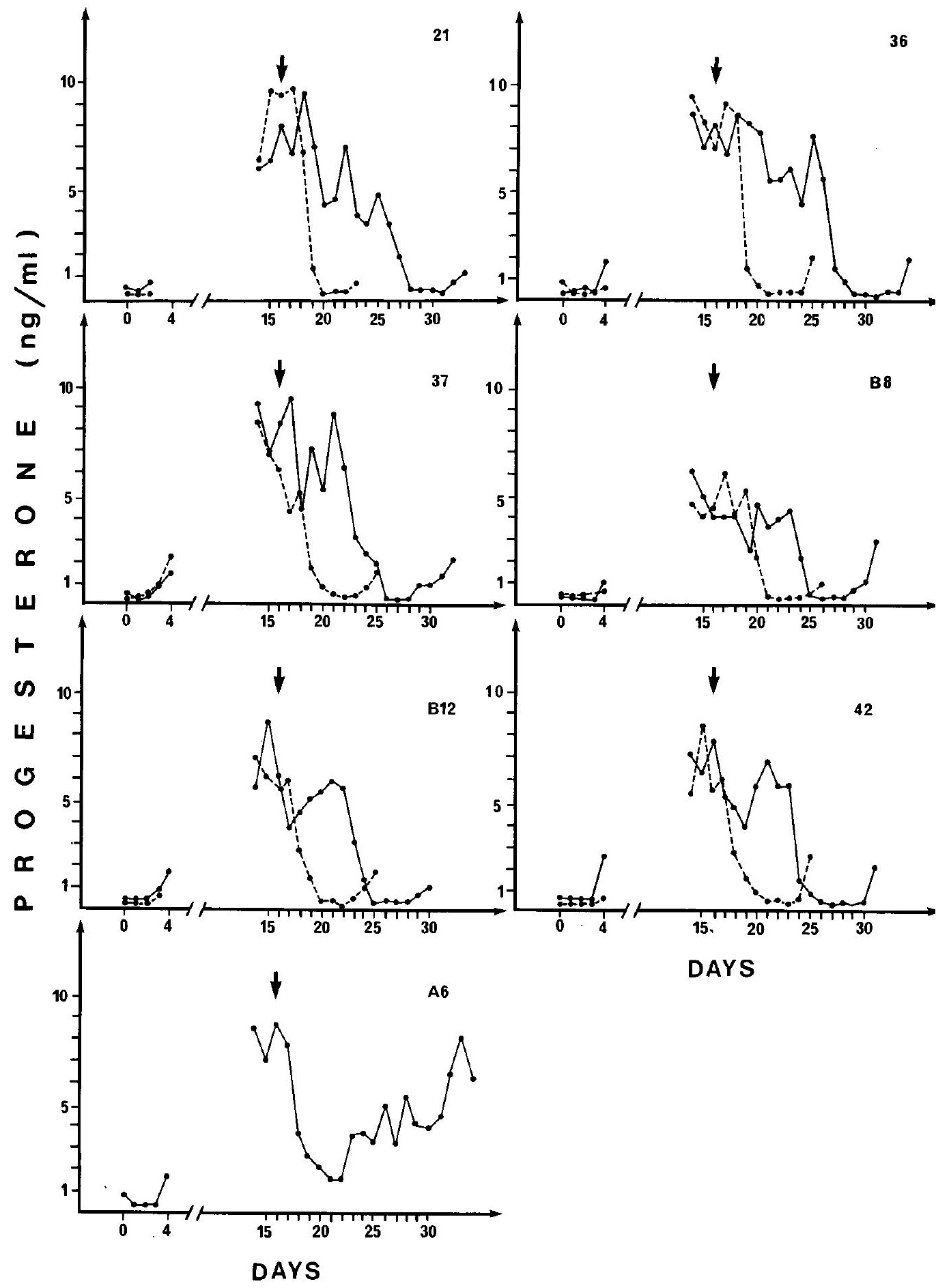

FIG. 4. - Individual progesterone patterns of 7 heifers from which day-16 conceptuses were removed. $\mathrm{O}------\mathrm{O}$ Progesterone concentrations measured throughout the control cycle, Progesterone concentrations measured throughout the cycle during which the conceptus was removed. 
Effect of intrauterine administration of conceptus tissue. - It was found by analysis of variance that mean estrous cycle length differed $(p<0.001)$ between the four treatment groups (table 2). Individual differences between groups were further investigated by a multiple comparison analysis.

TABLE 2

Effect of intrauterine administration of conceptus tissue on length of the estrous cycle (days).

\begin{tabular}{ccc} 
Treatment & $\mathrm{N}$ & $\begin{array}{c}\text { Interestrous Interval } \\
\text { (mean } \pm \text { S.D.) }\end{array}$ \\
\hline Controls & 10 & $22.3 \pm 1.0(1)$ \\
$\quad$ Saline & 3 & $19.0 \pm 1.0(2)$ \\
Conceptuses & 3 & $20.0 \pm 1.0(3)$ \\
$\quad$ (day 12) & & $27.0 \pm 1.0(4)$ \\
Conceptuses & 5 & \\
(day 16) & & \\
\hline
\end{tabular}

$N=$ Number of heifers.

2 vs 1 and 4 vs 1,2 or 3 , significant difference $p<0.001$.

3 vs 1 , significant difference $\mathrm{p}<0.01$.

3 vs 2 , N. S.

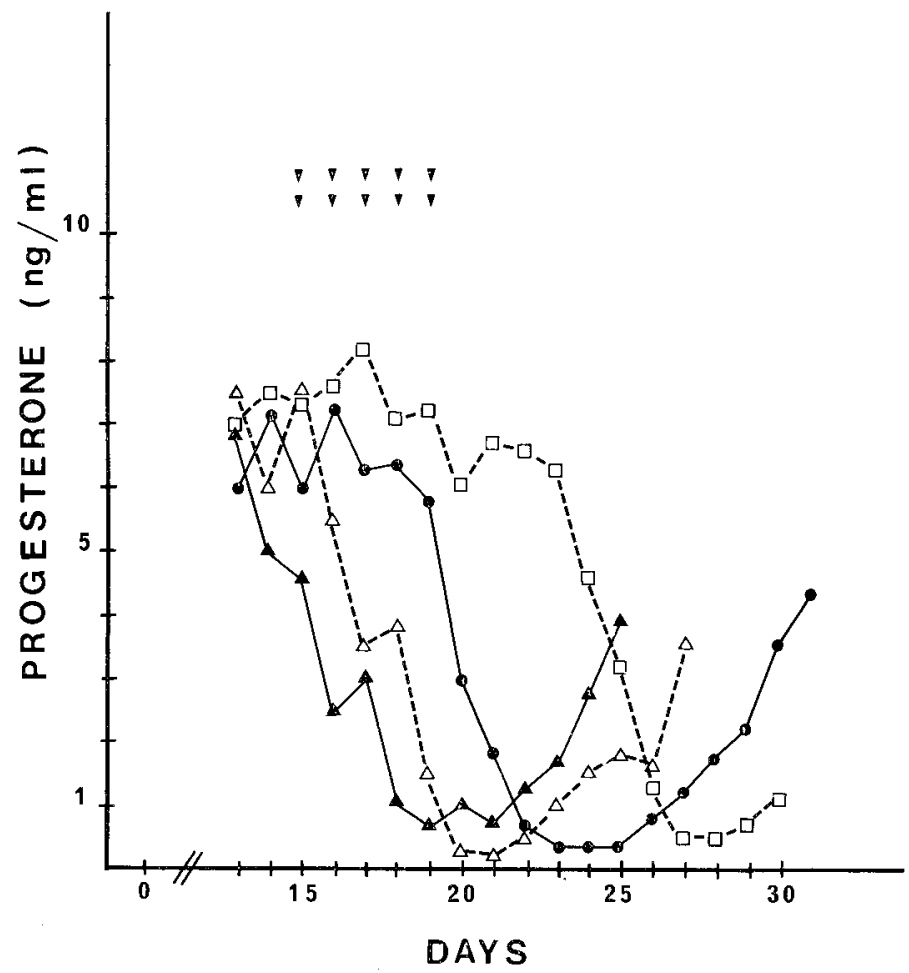

FIG. 5. - Progesterone profiles $(\bar{X})$ of control heifers $-(n=10)$ and after repeated transcer-

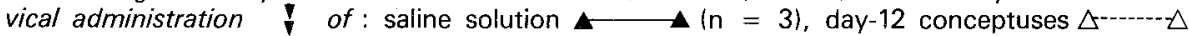
$(n=3)$ and day-16 conceptuses $\square-\square(n=5)$.

Reproduction, Nutrition, Développement $n^{\circ} 5$ A $1984 .-3$. 
Control animals, which received no intrauterine treatment, underwent complete luteolysis a mean 21 days after the preceding estrus. Luteolysis occured sooner (fig. 5) in heifers treated either with saline solution alone ( $p<0.001$ ) or with day-12 conceptuses ( $p<0.01$ ).

By contrast, when day-16 conceptuses were administrated, luteolysis occured 5 to 8 days later than in the other three groups. Interestrous intervals for these five heifers were 26, 26, 27, 28 and 28 days (table 2). These data demonstrate the antiluteolytic action of day-16 conceptuses administered transcervically.

No significant rise in plasma progesterone concentrations was observed after the introduction of day-16 conceptuses: the levels were very similar to those observed during a normal luteal phase before luteolysis.

\section{Discussion}

Effect of the uterine flushing procedure and conceptus removal on luteal function.

In contrast to data reported by Elsden et al., (1976) and Crister et al., (1980), no effect of the uterine flushing procedure on luteal function was found at any of the three stages of the estrous cycle studied. However, Crister et al., (1980) performed their studies during the early luteal phase (between days 5 and 8). These divergent results suggest that the sensitivity of the $C L$ to uterine handling may be different according to the stage of the estrous cycle. The fact that, in the present study, uterine flushing did not interfere with luteal function demonstrates that this method is suitable for mimicking embryonic death, at least at these early stages of conceptus development. The situation may be different during later stages of pregnancy. It was reported in the ewe (Dooley et al., 1974) that estrus and a decline in progesterone concentrations occured earlier after embryonic mortality simulated by uterine flushing than that induced by a colchicine injection.

The results obtained after embryo removal in our study fully confirm those obtained by Northey and French (1980) and show clearly that 9 and 14-day conceptuses do not produce an antiluteolytic signal or, at least, produce it in quantities too small to extend corpus luteum lifespan.

By contrast, after removal of day - 16 conceptuses, luteolysis was delayed by 5 to 7 days in all animals. This delay was longer than that reported by Northey and French after removal of older conceptuses (17 or 19 days). The better expression of the antiluteolytic action of the conceptuses found here may be due to the fact that each animal was its own control, thus minimizing the effect of individual variability. When conceptuses were removed 16 days after Al, progesterone concentrations between days 20 and 24 were slightly lower than those detected in pregnant animals at the same stage (data not shown), but remained higher than $2 \mathrm{ng} / \mathrm{ml}$ up to 2 days before complete luteolysis. This typical pattern of change in progesterone concentrations in these heifers may reflect the lack of a conceptus factor which stimulates progesterone production by the corpus luteum, as suggested by Lukaszewska and Hansel (1980). 
Moreover, from a practical viewpoint, embryonic death subsequent to day 15 would decreased the accuracy of early pregnancy diagnosis based on progesterone concentrations 21-24 days after breeding. Nevertheless, the incidence of such cases on cow fertility would be relatively low because the frequency of late embryonic mortality does not exceed $10 \%$ of the total number of Al's (Kummerfeld et al., 1978 ; Ball, 1978 ; Humblot, 1981).

\section{Effect of intrauterine administration of conceptus tissue on luteal function.}

Repeated intrauterine administration of saline solution decreased corpus luteum lifespan by 1 or 2 days. This trend is is in agreement with previous findings of Bartol et al., 1981a, who reported that repeated uterine manipulations and flushings increase prostaglandin $\mathrm{F} 2$, release. This may induce early luteolysis, especially if these treatments are performed at the end of the cycle when prostaglandin $\mathrm{F} 2{ }_{\alpha}$ receptor number and affinity in the corpus luteum are maximal (Bartol et al., 1981b).

After administration of 16-day conceptuses, luteolysis occurred a mean 26 days after the previous estrus. This time interval is 2 days longer than that reported by Northey and French (1980) who worked with a mixture of day-17 and day-18 conceptuses introduced into the uterine lumen by a surgical procedure between days 14 and 18 of the cycle. If such a difference could be considered significant, it would suggest that either day-16 conceptuses have greater antiluteolytic activity than day-17 or 18 conceptuses or that the transcervical administration of conceptuses interferes less than the surgical procedure with luteal function. The day-15 to day-19 period during which the embryos were administered might have affected luteolysis more than the day-14 to day-18 period. It may also be speculated that deep freezing was less detrimental to the antiluteolytic substance released by the conceptus than the homogenization procedure employed by Northey and French (1980).

The chemical nature of the signal(s) produced by the bovine conceptus remains unknown. $\mathrm{PGE}_{2}$ or similar compounds have been suggested as candidates for this signal, but they need to be administered chronically to extend corpus luteum function (Magness et al., 1981 ; Huie et al., 1981 ; Gimenez and Henricks, 1983). Moreover, it was found from a preliminary experiment (Dalla Porta and Humblot, 1983) that $\mathrm{PGE}_{2}$, administered by the same way as these conceptuses, was less potent than day-16 conceptuses in maintaining progesterone production by the corpus luteum. These observations suggest that other signals, such a proteins of trophoblastic origin (Martal et al., 1979 ; Heyman et al., 1982), may be necessary at the beginning of pregnancy. These proteins could also be involved in $\mathrm{PGE}_{2}$ or prostacyclin production or transfer (Marcus, 1981) from the uterus to the ovary.

In conclusion, it has been shown that the antiluteolytic and/or luteotropic factor(s) originating from the bovine conceptus is fully potent on day 16 of - gestation.

Reçu en janvier 1984 Accepté en avril 1984

Acknowledgements. - The authors gratefully acknowledge the excellent technical assistance of J.-L. Schwartz. 


\section{Résumé. Action antilutéolytique de l'embryon chez les bovins.}

Deux expériences ont été réalisées pour déterminer le jour auquel l'embryon commence à avoir un effet sur la fonction lutéale.

Dans l'expérience 1, 12 génisses non inséminées ont été collectées 9,14 et 16 jours après les chaleurs (4 par groupe). La même méthode a été utilisée pour prélever le conceptus chez 15 génisses gestantes $9(n=4), 14(n=5)$ et 16 jours $(n=7)$ après la fécondation. Les concentrations de progestérone ont été mesurées journellement pendant le cycle correspondant au retrait du conceptus (ou au lavage utérin seul) et pendant le cycle précédent. Chez les génisses non inséminées et quand les embryons ont été retirés 9 ou 14 jours après la fécondation la longueur du cycle sexuel comme les profils de progestérone n'ont pas été modifiés. En revanche, quand l'embryon a été retiré 16 jours après la fécondation, la lutéolyse est différée de 4 à 7 jours.

Dans l'expérience 2, 22 génisses ont été réparties en 4 groupes. Les génisses du groupe 1 n'ont reçu aucun traitement intra-utérin. Les animaux des groupes 2 et 4 ont reçu 2 fois par jour entre $J_{15}$ et $J_{19}$ du cycle dans la corne ipsilatérale au corps jaune les traitements suivants: groupe $2(\mathrm{n}=3) 0,25 \mathrm{ml}$ le sérum physiologique, groupe 3 $(n=3)$ deux embryons de $J_{12}$ dans $0,25 \mathrm{ml}$ de sérum physiologique, groupe $4(n=5)$ un embryon de $J_{16}$. Les concentrations de progestérone ont été déterminées à partir de $J_{13}$ jusque 4 jours après l'œstrus suivant. Aucun effet antilutéolytique n'a été trouvé après administration intra utérine d'embryons âgés de 12 jours. Par contre l'administration d'embryons de $\mathrm{J}_{16}$, a allongé la durée du cycle de 6 à 7 jours.

Les résultats de ces expériences suggèrent que le ou les facteur(s) lutéotrophiques ou antilutéolytiques provenant de l'embryon est (sont) actif(s) dès le $16^{\mathrm{e}}$ jour après la fécondation. La mortalité embryonnaire survenant à 16 jours ou plus tard provoque une extension de la durée de vie du corps jaune.

\section{Références}

BALL P. J. H., 1978. The relationship of age and stage of gestation to the incidence of embryo death in dairy cattle. Res. Vet. Sci, 25, 120-122.

BARTOL F. F., THATCHER W. W., LEWIS G. S., BLISS E. L., DROST M., BAZER F. W., 1981a. Effect of estradiol-17 $\beta$ on PGF and total protein content in bovine uterine flushings and peripheral plasma concentration of 13, 14 dihydro-15-keto- $\mathrm{PGF}_{2 \alpha}$. Theriogenology, 15, 345-357.

BARTOL F. F., THATCHER W. W., BAZER F. W., KIMBALL F. A., CHENAULT J. R., WILCOX C. J., ROBERTS R. M., 1981b. Effects of the estrous cycle and early pregnancy on bovine uterine, luteal and follicular responses. Biol. Reprod., 25, 759-776.

BEAL W. E., LUKASZEWSKA J. H., HANSEL W., 1981. Luteotropic effects of bovine blastocysts. J. anim. Sci, 52, 567-573.

BULMAN D. C., LAMMING G. E., 1978. Milk progesterone levels in relation to conception, repeat breeding and factors influencing acyclicity in dairy cows. J. Reprod. Fert., 59, 205-216.

CRISTER J. K., ROWE R. F., DEL CAMPO M. R., GINTHER O. J., 1980. Embryo transfer in cattle factors affecting superovulatory response, number of transferable embryos and length of post-treatment oestrous cycles. Theriogenology, 13, 397-405.

DALLA PORTA M. A., HUMBLOT P., 1983. Effect of embryo removal and embryonic extracts or $\mathrm{PGE}_{2}$ infusions on luteal function in the bovine. Theriogenology, 19, 122 (Abstr.).

DOOLEY M., TOMASZEWSKA M. W., EDEY T. N., 1974. Luteal function following embryonic mortality in ewes. J. Reprod. Fert, 36, 462.

ELSDEN R. P., HASLER J. F., SEIDEL G. E., 1976. Nonsurgical recovery of bovine eggs. Theriogenology, 6, 523-532.

GIMENEZ T., HENRICKS D. M., 1983. Prolongation of the luteal phase by prostaglandin $E_{2}$ during the estrous cycle in the cow. A preliminary report. Theriogenology, 19, 693-700.

HENDERSON K. M., SCARAMUZZI R. J., BAIRD D. T., 1977. Simultaneous infusion of prostaglandin $E_{2}$ antagonizes the luteolytic action of prostaglandin $F_{2 \alpha}$ in vivo. Endocrinology, 72, 379-383. 
HEYMAN Y., CAMOUS S., FEURE H., MARTAL J., 1982. Maintien du corps jaune après transplantation utérine de vésicules trophoblastiques chez la vache et la brebis cycliques. In Proceed. 2nd world Conf. on Embryo transfer and in vitro fertilization (Annecy), p. 92 (Abstr.).

HUIE J.-M., MAGNESS R. R., REYNOLDS L. P., HOYER G., HUECKSTEADT T., COLCORD M., STALCUP B., WHYSONG G. L., WEEMS C. W., 1981. Effect of chronic ipsilateral or contralateral intrauterine infusion of prostaglandin $E_{1}\left(P G E_{1}\right)$ on luteal function of unilaterally ovariectomized ewes. Prostaglandins, 21, 945-955.

HUMBLOT P., 1981. Respective incidence of late embryonic mortality and post-insemination anoestrus in late returns to oestrus in dairy cows, 298-304. In : Factors influencing fertility in the post partum cow (H. KARG, E. SCHALLENBERGER), Martinus Nijhoff Publ.

HUMBLOT P., DALLA PORTA M. A., SCHWARTZ J.-L. 1981. Etude de la mortalité embryonnaire. Elev. Insém., 183, 3-13.

KUMMERFELD H. L., OLTENACU E. A. B., FOOTE R. H., 1978. Embryonic mortality in dairy cows estimated by nonreturn to service, estrus and cyclic milk progesterone patterns. J. Dairy Sci, 61, 1773-1777.

LEWIS G. S., JENKINS P. E., FOGWELL R. L., INSKEEP E. K., 1978. Concentrations of prostaglandins $E_{2}$ and $F_{2 \alpha}$ and their relationship to luteal function in early pregnant ewes. J. anim. Sci., 47, 1314-1323.

LUKASZENWSKA J. H., HANSEL W., 1980. Corpus luteum maintenance during early pregnancy in the cow. J. Reprod. Fert., 59, 485-493.

MAGNESS R. R., HUIE J. M., HOYER G. L., HUECKSTEADT T. P., REYNOLDS L. P., SEPERICH G. J., WHYSONG G., WEEMS C. W., 1981. Effect of chronic ipsilateral or contralateral intrauterine infusion of prostaglandin $E_{2}\left(P_{G} E_{2}\right)$ on luteal function of unilaterally ovariectomized ewes. Prostaglandins Med., 6, 389-401.

MARCUS G. J., 1981. Prostaglandin formation by the sheep embryo and endometrium as an indication of maternal recognition of pregnancy. Biol. Reprod., 25, 56-64.

MARTAL J., LACROIX M.-C., LOUDES C., SAUNIER M., WINTENBERGER-TORRĖS S., 1979. Trophoblastin, an antiluteolytic protein present in early pregnancy in sheep. J. Reprod. Fert., 56, 63-73.

NORTHEY D. L., FRENCH L. R., 1980. Effect of embryo removal and intrauterine infusion of embryonic homogenates on the lifespan of the bovine corpus luteum. J. anim. Sci, 50, 298-302.

OZIL J.-P., HEYMAN Y., RENARD J.-P., 1979. An instrument for transcervical recovery of embryos from heifers. Theriogenology, 11, 173-183.

PRATT B. R., BUTCHER R. L., INSKEEP E. K., 1979. Effect of continuous intrauterine administration of prostaglandin $E_{2}$ on lifespan of corpora lutea of non-pregnant ewes. $J$. anim. Sci., 48, 1441-1446.

THIBIER M., CASTANIER M., TEA N., SCHOLLER R., 1973. Concentrations plasmatiques de la $17 \alpha$ hydroxyprogesterone au cours du cycle de la vache. C. R. Acad. Sci. Paris, sér. D, 276, 3049-3052.

THIBIER M., SAUMANDE J., 1975 . Estradiol $17 \beta$, progesterone and $17 \alpha$-hydroxyprogesterone in cows around oestrus. J. Steroid Bioch., 6, 1433-1437.

YENIKOYE A., MARIANA J. C., LEY J. P., JOLIVET E., TERQUI M., LEMON-RESPLANDY M., 1981. Modèle mathématique de l'évolution de progesterone chez la vache : applications et mise en évidence de différences entre races. Reprod. Nutr. Dévelop., 21, 561-575. 